\title{
RIGHTS OBSERVANCE OF SOCIALLY VULNERABLE GROUPS IN MASS MEDIA: EDUCATIONAL PRAXES
}

\author{
KOVALOVA Tetiana, \\ PhD (Social Communications), e-mail: tatkovalova@gmail.com; \\ SYPCHENKO Inna, \\ PhD (Social Communications), e-mail: innasypchenko@ukr.net; \\ HAVRYLIUK Inna, \\ PhD (Social Communications), e-mail: havriliuk.inna@gmail.com; \\ Sumy State University, 2, Rymsky-Korsakov St., Sumy, 40007, Ukraine
}

The article considers educational praxes for journalist students concerning the rights observance of socially vulnerable groups in mass media. The methodology, theoretical and practical aspects of teaching and the main educational content used in teaching are highlighted within the frame work of the topics. The knowledge importance of the presentation of topics concerning socially vulnerable groups by media professionals is emphasized. The special attention is paid to interdisciplinary relationships in the context of studying the topics concerning socially vulnerable groups.

Key words: socially vulnerable groups, human rights, mass media, journalist students, training.

\section{ДОТРИМАННЯ ПРАВ СОЦІАЛЬНО ВРАЗЛИВИХ ГРУП У ЗАСОБАХ МАСОВОЇ ІНФОРМАЦІї: ОСВІТНІ ПРАКТИКИ}

Стаття присвячена розгляду навчальних практик опрацювання зі студентали-журналістами тел, що стосуються дотрилання в засобах масової інфорлацї прав соціально вразливих груп. Розкрито летодологічні прийоли, теоретико-практичні аспекти викладання, основний зміст навчального контенту, використовувані в процесі викладання окресленої телатики. Наголошується на значущості знання ледійникали особливостей подання тели щодо соціально вразливих груп. Акцентується увага на міжпредлетних зв'язках у контексті вивчення тел, що стосуються соціально вразливих груп.

Ключові слова: соціально вразливі групи, права людини, ЗМI, студенти-журналісти, тренінг.

I

ntroduction. One of the most extremely important principles of democratic countries is the knowledge and observance of human rights. European Union experience is valuable in this aspect, as the mechanisms of protecting and realizing the rights of various layers of the population, including socially vulnerable, have long been developed in these countries. Ukraine's persistent attempts to join the European Union and application of European experience require studying. Of special urgency, this issue is in mass media as they are called to shape public values. Unfortunately, there is still lack of tolerance towards socially vulnerable groups in Ukrainian mass media. "While constructing the image of reality, mass media reflect a society deprived of social diversity, focusing on actions and behaviour of political, financial and cultural elites. Accordingly, the unequal presentation of social groups in mass media shows social and economic stratification of society and the ways of unequal distribution of resources. Summing up, one can say that mass media symbolically represent the hierarchy of social inequality. This conclusion contrasts with the basic principles of the mass media functioning, which include objectivity and impartiality of mass media as a mediator, a guide among various social sectors and social groups» [1]. This fact can be explained by the ignorance of journalists about the legal documents concerning socially vulnerable groups, the ethical principles 
of reporting information on this category, the peculiarities of working with it and finally by backward stereotypical attitude towards the abovementioned group, the lack of personal and professional responsibility for the said and written. Such a situation in media should stimulate its solution. The media educational praxes should begin from the first years of journalist students training. Thus, the development of comprehensive theoretical and practical approach in order to acquaint students studying journalism with the peculiarities of reporting information in media about such a category as socially vulnerable groups is relevant.

The research aim is to develop and reveal educational praxes that are applied at the Department of Journalism and Philology of Sumy State University while acquainting students with the basic principles of working with information on socially vulnerable groups.

The research object is the problem of rights observance of socially vulnerable groups by mass media in the framework of professional training of journalist students.

The research subject is the teaching methodology of professional disciplines in the context of studying the outlined topic.

Methodology of Research. The methodology of paper is based on the systematic approach that allows identifying the media education praxes relating to the study of the rights of socially vulnerable groups in media which contribute to revealing the basic principles to be followed by the teaching staff which trains students studying journalism. The following methods as analysis of documentary information, descriptive, systematic methods, and questionnaires were used at different stages of research to reveal the problem and solve the tasks.

Results and discussions. It is worth mentioning, that today most Ukrainians have biased stereotyped attitudes towards people who are conventionally nominated as socially vulnerable groups. The survey "What Ukrainians know and think of human rights: nationwide research" state that "more than half of Ukrainians (about $60 \%$ ) admitted the presence of discrimination problem in the society. $<\ldots>$ The age discrimination was the most often mentioned (about $37 \%$ of respondents mentioned it) and disabled people discrimination (about $33 \%$ )» [2, p. 27]. The following data are also impressive: «Despite the declared inadmissibility of discrimination, the general readiness of Ukrainians to approve and support the discrimination of certain groups appeared to be high. Thus, $66 \%$ of respondents agree that the rights of drug dependents may be limited, almost $53 \%$ support the possibility of limiting the rights of former convicts, ... the significant proportion of respondents permeit restricting the rights of gypsy and LGBT community (47\% and $46 \%$ res pectively)» [2, p. 27].

It is alarming that the most serious discrimination situation is in the south $(47.6 \%)$ and in the east $(45.3 \%)$ of Ukraine [2, p. 29]. As Sumy oblast is situated in the northeastern part of Ukraine, it is one of the most intolerant. As we see, the discrimination problem of certain groups requires immediate solving, it is urgent not only in all-Ukrainian, but also in the regional dimension. It is also urgent for mass media in Sumy oblast, journalist students, in particular, who will continue to shape media image of their region.

Ukrainians call media the main way for obtaining information about human rights and shaping the perception of the above mentioned problem $(56.9 \%$ among other ways) [2, p. 44]. Marina Tuneva, the lecturer of School of Journalism and Public Relations points out that «media play a key role and are responsible for establishing relations between people and building a democratic society. Their task includes objective and truthful representation of different communities in society and the promotion of respect for the diversity connected with ethnic origin, religious beliefs, sexual orientation or other differences between people» [3, p. 25]. The most powerful source of information among media is television ( $75.1 \%$ of respondents receive information on TV); the sec- 
ond place belongs to Internet editions (29.7\% of respondents ); the third place is taken by newspapers (22.8\% of respondents), radio (12.9\% of respondents), the last place in this list belongs to so-called social media, which is social networks, Internet forums (7.9 $\%$ of respondents) [2, p. 44].

It is necessary to point out that today there is no an educational course studying the coverage peculiarities of materials concerning socially vulnerable groups in Ukraine. In our opinion, this is not acceptable. The issue of compulsory study of human rights in media is urgent. Taking into account the importance of the above mentioned, the correspondent topics were introduced as a module into the discipline «Professional Ethics and Media Law», which is taught at the Department of Journalism and Philology of Sumy State University.

It should be stressed that professional media approaches to coverage of the rights observance of socially vulnerable strata of the population is almost not considered in academic manuals and textbooks on journalistic ethics, media law. However, Ukrainian media education has been recently replenished by methodological works on the mentioned issue. They include the manual «Gender Media Praxes» [4], the manual on inclusive decision-making for mass media «Nothing for us without us» [5], study guide «Social Issues in Newspapers» [6].

The professional standards of media professionals in the context of this issue are described in the reference books which are published in the framework of certain projects initiated and implemented by international organizations, the representative of European countries. This is, for example, the texts collection «The Hate Speach and Media: International Standards and Approaches» [3]. The following additional informational and educational resources may also be useful for media professionals: «Formation of tolerant attitude towards children affected by HIV / AIDS: peculiarities of volunteer training» [7], "Prevention and counteraction of discrimination in Ukraine» [8], «Guidelines on Discrimination» [9] etc.

Before considering the educational praxes used while developing this issue, it should be mentioned what is meant by socially vulnerable groups.

Socially vulnerable groups are "groups of people who have limited resources for independent satisfaction of needs and realization of rights, being in usual conditions, and people who are in particularly difficult social conditions due to circumstances beyond their control» [10] These groups include the following categories: disabled people, ethnic and national minorities, migrants, refugees, LGBT communities, drug dependents, former convicts, unemployed, homeless people, internally displaced persons, people of certain political and religious beliefs, persons experiencing or suffered from physical or psychological abuse, HIV positive people etc.

"Observance of the rights of socially vulnerable groups in mass media" module is delivered in the form of lectures, workshops, which is traditional for higher education institutions.

The lectures provide theoretical material within the framework of the highlighted issues. Moreover, some lectures are delivered in the form of trainings. Our observations testify that this is the most effective method of work, as it gives an opportunity to develop professional competency due to interactive learning. It is necessary to mention that some lecturers of the Department of Journalism and Philology of Sumy State University are undergoing the advanced training in the framework of the course «Human Rights Academy for Journalists», where they acquired experience in conducting the abovementioned classes. It was possible due to the support of United Nations Development Programme in Ukraine and Ministry of Foreign Affair of Denmark.

Traditional trainings consist of several components: an introductory students' survey as to perception of socially vulnerable groups, a presentation of the main theoretical principles (principles of journalist work with specific categories of socially vulnerable 
groups, monitoring results of media as to topics coverage of about socially vulnerable groups, observance of their rights etc.), if possible, speeches of the representatives of authorities, civil organizations and, in fact, socially vulnerable groups and the final questionnaire, which should show how the attitudes of journalist students as to the issue have changed.

The practical classes are the form of seminars, discussions, mini-conferences. The topics are developed and offered on the basis of lectures. For example, the students have to monitor the media materials as to coverage of the issues of socially vulnerable groups, the ethics observance by the media professionals and write a review and analytical material, also create their own material (a publication for printed or online media, a television or radio spot). The aim is not only to check the knowledge, but also to form the ability to analyze, express opinion as to the issue.

Such interactive forms of learning as thematic games, problem solving are introduced during lectures and practical classes. They contribute to gaining personal experience by students, forming of communication ethics, moral and ethical professional standards.

Instrument and Procedures

Let us give an example of one of the classes having the form of a training.

The training topic was media coverage of the problems of disabled people - «Pain spot of disability coverage in the regional mass media: between pity and excessive heroism». The class duration was 1 hour 20 minutes ( 2 academic hours).

The event was attended by the first year journalist students, a lecturer-moderator as well as by the representative of training and production enterprise of the Ukrainian Association of the Blind, Anatoliy Voronovskyi and a wheelchair person, public activist Oleksandr Osadchyi.

The preliminary preparations were made. The senior students made a video where they interviewed the first year students, who were the training participants, and who were asked the following questions: 1 . Do you think there is discrimination in Ukraine, if any, then of what kind? 2. Do disabled people feel free in our city? Are educational, medical and administrative institutions, cinemas, theaters, restaurants accessible to them? 3. Is it worth moving all disabled people to a separate place outside the city with all necessary conditions for their life: absence of stairs, sliding broad doors, sound crosswalks, available elevators etc.?

Training course:

1. Greeting. Introducing the guests.

2. Watching the video with the interview of training participants ( 5 min.).

3. Interactive game «Imaginary City» $(15 \mathrm{~min}$.). The students are divided into three groups that perform the following roles: the first group is the representatives of public organizations; the second group is the executive power; the third group is the legislative power.

Situation: imagine a city where only disabled people in wheelchairs live. The children born in such families are settled outside the city. There are no stairs all over the territory; the ceilings height in all premises does not exceed $150 \mathrm{~cm}$. A man and a woman come to the city, they can move without a wheelchair. Their height is 185 and $170 \mathrm{~cm}$ respectively. They ask for a shelter in the city community. Suggest specific measures to be taken by each of three groups in this situation.

4. Brief discussion of the video and the game (10 min.).

5. Presentation of a lecturer-moderator (10 min.): disability notion, people with limited mobility, accessibility, types of barriers (institutional, physical, informational, mental), disabled people: language and etiquette etc.

6. Guests speeches (10 min.). The life of disabled people in our city: problems and positive changes. The role of public and volunteer organizations in promoting the ideas of «reasonable accommodation» and "universal design» . 
7. Watch the video «Impasse» about stereotyped thinking (https://www.youtube. com/watch? $\mathrm{v}=$ SjcqpUwpP1U) (5 min.)

8. Video discussion. How does stereotyped thinking affect the work of a journalist? (15 min.).

\section{Summing up (5 min.).}

10. Home assignment: 1. To monitor Sumy oblast mass media for the last three months. Identify materials with a disability issue. Determine: the number of materials (neutral; depicting disabled people as heroes; excite pity to such people); news peg; objectivity; presence or absence of paid journalism signs; balance; emotionality. 2 . Create material about disabled people avoiding stereotyped approach.

Discussion. It should be emphasized that the great attention to the issue of rights observance of socially vulnerable groups in media is paid not only during the study of the discipline «Professional Ethics and Media Law». The Department of Journalism and Philology of Sumy State University, taking into account the importance of the abovementioned topic, made a decision to implement the basic concepts, approaches of socalled social journalism in the context of interdisciplinary relationships. For this purpose, a number of methodological seminars, trainings for lecturers were held; the main steps as to application of integrated learning were discussed. Therefore, the main ideas concerning the work of media professionals with socially vulnerable groups and the peculiarities of information support of this topic are incorporated into the cycle of professionally oriented disciplines: «Mass Media Issues», «Informational Genres», "Analytical Genres», «Literary and Op-ed Journalism», «Representation Forms in Journalism», "News Agency Journalism», "Media Office», "New Media», "Internet Journalism», «Photojournalism», «Radio Production», «TV Production».

For example, the laboratory classes of «Radio Production» suggest creating thematic news for future media professionals, author programs on social issues. The students work in improvised editorial teams, they look for stories for news and programs, heroes, experts, create information products, record in the radio studio and edit. In the end, they listen and discuss the created piece.

«TV Production» discipline pays great attention to such a component as the work with a hero (a representative of socially vulnerable groups) while making the program, ethics and professional standards to be respected by the members of the crew. The specific examples of television programs are considered, where the professional standards as to representatives of socially vulnerable groups were violated.

The fact that classes devoted to observance of the rights of socially vulnerable people have positive effect can be traced on the materials example of students studying at the Department of Journalism and Philology of Sumy State University. It is gratifying to mention the result of their work can be found in both national and regional media. For example, it is the story of Oleksandra Tokar «Equals», which tells about how it is to be a prisoner and a social worker in prison at the same time; about life and socialization of those who are behind the bars (http://life.pravda.com.ua/society/2017/10/24/227084/); Maria Lahuta storytelling «Creativity Stronger than War: Indian Patterns of ATO Veteran» (https://uain.press/articles/tvorchist-sylnisha-za-vijnu-indianski-vizerunkyveterana-ato/) tells about a disabled person (ATO participant) who was able to find the meaning of life in creativity; Oleksandr Kovalyov's video «Quality Test Not Available / Available Sumy? » https://www.youtube.com/watch?v=toBiI2pidiw\&t=16s) deals with the access problem of disabled people to public accommodation etc.

The issue of rights observance of socially vulnerable groups in media is urgent and of interest for journalist students. The fact that proves it is that many future media professionals prepare bachelor and master theses on the abovementioned topic. Moreover, the bachelor thesis involves the creation and presentation of an information product (or project) on selected topic in various media. The master thesis is a scientific research. 
Conclusions. Thus, there is the urgent need in more tolerant coverage of the issue of socially vulnerable groups, compliance with the journalistic standards in the coverage of issues related to this group. This issue is also important in the professional training of journalist student who have to change the media image of both Ukraine and their region, in particular, due to new knowledge and European mass media approaches. We believe that the formation of professional standards, the system of moral and ethical values should begin on the first years of journalism students training. Unfortunately, Ukrainian higher educational establishments, which train journalists, have not developed uniformed media education mechanisms designed to settle this issue. Taking into account the issue importance the correspondent course within the discipline «Professional Ethics and Media Law» was introduced at the Department of Journalism and Philology of Sumy State University. Other practice-oriented disciplines also consider the abovementioned issue. The best form of media education in the context of studying the abovementioned topic is a training that applies the principle of practical journalism.

1. Shenderovskyi, K. (2013). Institutionalization Prerequisites of Media Communications in solving social issues. Ukrainske zhurnalistykoznavstvo. Kyiv. Issue 14. P.40-49.

2. Bekeshkina, I., \& Pechonchyk, T., \& Yavorskyi V. (2017). What Ukrainians know and think of human rights: nationwide research. Kyiv.

3. Bondarenko, O., \& Butkevych, M., \& Fedorovych, I. (2015). Hate speech in Mass Media: international standard and approaches. Kyiv.

4. Shturkhetskyi, S. (2014). Gender Media Praxis: Study guide for gender equality and nondiscrimination for graduate students. Kyiv.

5. Vyrtosu, I.H., \& Azin, V.O., \& Bayda, L.Yu., \& Hoss, N., \& Zhdan,P.M., \& Fletcher, A. (2015). Nothing for us without us: manual for inclusive decision-making in mass media. Kyiv: Lenvit.

6. Lavryk, O. V. (2010). Social Issues in Newspapers: study guide for journalist students. Kharkiv: V.N. Karazin KNU.

7. Husak, N., \& Dmytryshyna, N., \& Dovbakh, H., \& Zharuk ,I., \& Zinchenko, A., \& Matiiash, O., \& Nazaruk,V., \& Panfilova, O., \& Romanova, N. (2011). Formation of tolerant attitude towards children affected by HIV / AIDS: peculiarities of volunteer training. Kyiv: International Charitable Foundation «International HIV/AIDS Alliance in Ukraine».

8. Ponomarov, S. Yu., \& Fedorovych, I. Yu. (2014). Prevention and counteraction of discrimination in Ukraine: Manual for state and local authorities. Kyiv: International Organization for Migration in Ukraine.

9. Yelihulashvili, M., \& Fedorovych, I., \& Ponomarov, S. (2015). Guidelines on Discrimination: Manual. Kyiv.

10. Social work with socially vulnerable categories (groups). Retrieved $1 / 11 / 2017$, from http://moodle.socosvita.kiev.ua/moodledata/filedir/09/20/0920e3108c21981f344ac5e33b46e7 $470 \mathrm{dc} 1 \mathrm{ac} 88$

1. Шендеровський $K$. Передумови інституціалізації медіакомунікацій при розв'язанні соціальних проблем. Українське журналістикознавство. К., 2013. Вип. 14. С. 40-49.

2. Бекешкіна I., Печончик T., Яворський В. Що українці знають і думають про права людини : загальнонаціональне дослідження / за заг. ред. Т. Печончик. К., 2017. 308 с.

3. Мова ворожнечі у ЗМІ: міжнародні стандарти та підходи / ред. та упоряд. О. Бондаренко, М. Буткевич, І. Федорович. К., 2015. 63 с.

4. Гендерні медійні практики: навч. посіб. із гендерної рівності та недискримінації для студ. вищ. навч. закладів / за заг. ред. С. Штурхецького. К., 2014. 206 с.

5. Нічого для нас без нас : посіб. з інклюзивного прийняття рішень для засобів масової інформації / упоряд. : Азін В. О., Байда Л. Ю., Госс Н., ЖЖдан П. М., Флетчер А. К. : Ленвіт, 2015. 92 с.

6. Лаврик О. В. Соціальна проблематика газетних виступів : навч.-метод. посіб. для студ. зі спец. «Журналістика». Х. : ХНУЦ ім. В. Н. Каразіна, 2010. 72 с.

7. Формування толерантного ставлення до дітей, яких торкнулася проблема ВІЛ/СНІДу: особливості підготовки волонтерів : метод. посіб. / Гусак Н. та ін. К. : МБФ «Міжнародний Альянс з ВІЛ/СНІД в Україні», 2011. 128 с. 
8. Поноларьов С. Ю., Федорович І. Ю. Запобігання та протидія дискримінації в Україні : посіб. для працівників органів державної влади та місцевого самоврядування. К. : Міжнародна організація з міграції, Представництво в Україні, 2014. 74 с.

9. Єлігулашвілі М., Федорович I., Поноларьов С. Організація навчання з питань дискримінації : практ. посіб. К., 2015. 136 с.

10. Соціальна робота з соціально вразливими категоріями (групами). URL: http://moodle. socosvita.kiev.ua/moodledata/filedir/09/20/0920e3108c21981f344ac5e33b46e7470dc1ac88 (дата звернення: 10.04.2018).

\title{
УДК $007: 378$ \\ ДОТРИМАННЯ ПРАВ СОЦІАЛЬНО ВРАЗЛИВИХ ГРУП У ЗАСОБАХ МАСОВОЇ ІНФОРМАЦІЇ: ОСВІТНІ ПРАКТИКИ
}

\author{
Ковальова Тетяна, канд. наук із соц. комунік., е-mail: tatkovalova@gmail.com; \\ Сипченко Інна, канд. наук із соц. комунік., e-mail: innasypchenko@ukr.net; \\ Гаврилюк Інна, канд. наук із соц. комунік., e-mail: havriliuk.inna@gmail.com, \\ Сумський державний університет, вул. Римського-Корсакова, 2, Суми, 40007, Україна.
}

Вступ. В українських вищих навчальних закладах, де провадиться підготовка фахівців за спеціальністю «Журналістика», і досі не випрацювані єдині механізми щодо викладання тем, які стосуються дотримання в ЗМІ прав соціально вразливих груп. Проте це питання є вкрай актуальним в системі професійної підготовки майбутніх масмедійників.

Метою є розробка та висвітлення навчальних практик, що застосовуються на кафедрі журналістики та філології Сумського державного університету під час ознайомлення студентів-журналістів із базовими принципами роботи з інформацією про соціально вразливі групи населення.

Методологія. Базується на системному підході, який дозволяє виявляти практики вивчення медіа, пов'язані з висвітленням прав соціально вразливих груп у засобах масової інформації. На різних стадіях дослідження використані такі методи, як аналіз документальної інформації, систематизація та ін.

Результати. У статті розкрито методологічні прийоми, теоретико-практичні аспекти викладання, основний зміст навчального контенту, що використовується в процесі вивчення окресленої проблематики. Було встановлено, що тема дотримання у ЗМІ прав соціально вразливих груп є затребуваною, цікавить студентів-журналістів. Вони активно впроваджують отримані знання у медіапрактику. Враховуючи важливість проблеми, на кафедрі журналістики та філології СумДУ був запроваджений відповідний курс у межax дисципліни «Професійна етика та медіаправо». Також вищезазначена проблематика розглядається під час вивчення інших практико орієнтованих курсів. Акцентується увага на міжпредметних зв'язках у контексті вивчення тем, що стосуються соціально вразливих груп. Найкращою формою медіаосвітнього процесу в контексті вивчення вищезазначеної теми визначено тренінги, що реалізують принцип практичного журналізму.

Висновки. Формування професійних стандартів, система моральних та етичних цінностей має починатися з перших років підготовки студентів-журналістів. Українські вищі навчальні заклади, які виховують журналістів, не розробили механізми формування засобів масової інформації для вирішення цього питання. Порушена проблема є першим кроком, який надалі розроблятиметься, поглиблюватиметься й іншими закладами вищої освіти, де готують студентів-журналістів.

Ключові слова: соціально вразливі групи, права людини, ЗМI, студенти-журналісти, тренінг. 